
\title{
$\angle S$ Research Square \\ Linking Omega-3 Polyunsaturated Fatty Acids in Natural Diet with Brain Size of Wild Consumers
}

Libor Zavorka ( $\sim$ liborzavorka@email.cz)

WasserCluster Lunz https://orcid.org/0000-0002-0489-3681

Magnus Lovén Wallerius

University of Gothenburg: Goteborgs Universitet

Martin Kainz

WasserCluster Lunz

Johan Höjesjö

University of Gothenburg: Goteborgs Universitet

\section{Research Article}

Keywords: essential fatty acids, neurogenesis, encephalization, animal cognition, ecosystem functioning, biological invasions

Posted Date: January 12th, 2022

DOI: https://doi.org/10.21203/rs.3.rs-1167482/v1

License: (c) (1) This work is licensed under a Creative Commons Attribution 4.0 International License. Read Full License 


\section{Abstract}

Omega-3 long-chain polyunsaturated fatty acids (n-3 LC-PUFA) are key structural lipids and their dietary intake is essential for brain development of virtually all vertebrates. The importance of n-3 LC-PUFA has been demonstrated in clinical and laboratory studies, but little is known about how differences in availability of n-3 LC-PUFA in natural prey influence brain development of wild consumers. The numerous consumers foraging on the interface of aquatic and terrestrial food webs can differ substantially in their intake of n-3 LC-PUFA, which may lead to differences in brain development, yet, this hypothesis remains to be tested. Here we use the previously demonstrated shift towards higher reliance on n-3 LC-PUFA deprived terrestrial prey of native brown trout Salmo trutta living in sympatry with invasive brook trout Salvelinus fontinalis to explore this hypothesis. We found that the content of n-3 LC-PUFA in muscle tissues of brown trout decreased with increasing consumption of n-3 LC-PUFA deprived terrestrial prey. Brain volume was positively related to content of the n-3 LC-PUFA, docosahexaenoic acid, in muscle tissues of brown trout. Our study thus suggests that increased reliance on low quality diet of n-3 LC-PUFA deprived subsidies can have a significant negative impact on brain development of wild trout. Our findings are important, because ongoing global change is predicted to reduce the availability of dietary $\mathrm{n}$ 3 LC-PUFA across food webs and we showed here a first evidence of how brain of wild vertebrate consumers response to scarcity of n-3 LC-PUFA content in natural prey.

\section{Introduction}

Omega-3 long-chain polyunsaturated fatty acids (n-3 LC-PUFA), in particular docosahexaenoic acid (DHA; 22:6n-3), are essential for optimal functioning of metabolism and neural development of most vertebrate consumers (Pilecky et al. 2021; Twining et al. 2021). DHA is highly retained by vertebrates (Pilecky et al. 2021) and it has been shown to be a dominant building block of brain of fishes (Ebm et al. 2021), birds (Speake \& Wood 2005), and mammals (Innis 2007). Laboratory feeding studies have shown that increased dietary intake of n-3 LC-PUFA facilitates brain growth and neuron proliferation in rodents (Kawakita et al. 2006), passerine birds (Hall et al. 2014), and freshwater (Lund et al. 2012) and marine fishes (Ishizaki et al. 2001). These dietary induced changes in brain development have also been shown to influence cognitive skills of vertebrate consumers (Lund et al. 2012; Sugasini et al. 2017; Pilecky et al. 2021) and could thus potentially have a direct impact on their fitness in the wild (Boogert et al., 2018). Yet, little is known about how n-3 LC-PUFA content in natural diets influences the development of vertebrate brain in the wild.

Primary producers drive the availability of dietary n-3 LC-PUFA in prey communities, which is generally lowest in terrestrial, intermediate in freshwater, and highest in marine food webs (Hixson et al. 2015; Brett et al. 2017; Colombo et al. 2017). Vascular plants dominating primary production in terrestrial ecosystems can synthesize only short chain n-3 PUFA alpha-linoleic acid (ALA, 18:3n-3), while multiple aquatic primary producers, especially microalgae, can synthesize long-chain n-3 PUFA de novo, mainly eicosapentaenoic acid (EPA; 20:5n-3), but also DHA (Arts et al. 2009; Brett et al. 2017; Twining et al. 2016). The dominant determinant of n-3 LC-PUFA synthesis by primary producers appears to be their 
phylogeny (Twining et al. 2016; Marzetz et al. 2017). Therefore, the structure of the primary producer community is determinant of the n-3 LC-PUFA availability to herbivores (Marzetz et al. 2017; Guo et al. 2018) and to consumers at higher trophic levels (Guo et al. 2021). Observational studies on wild European perch Perca fluviatilis (Scharnweber et a. 2021) and Eastern Phoebe Sayornis phoebe (Twining et al. 2019) have shown that diet of individuals from the same species can differ substantially in the content of n-3 LC-PUFA due to intra-specific niche partitioning (Araújo et al. 2011). Therefore, differences in diet quality in wild vertebrate consumers can potentially be large enough to cause intra-specific divergence in brain development, but this hypothesis remains to be tested.

Dietary ALA and EPA are utilized by many vertebrates for internal synthesis of DHA (Murray et al. 2014; Twining et al. 2021; Závorka et al. 2021). However, the synthesis of DHA from short-chain ALA requires more conversion steps and thus more energy than the synthesis from long-chain EPA (Pilecky et al. 2021; Twining et al. 2021). This energy trade-off can lead to the lower capacity of consumers feeding on diet deprived of n-3 LC-PUFA to synthetize DHA and retain it in the brain (Závorka et al. 2021; Pilecky et al. 2021). In addition to the diet quality, this energy trade-off can be amplified by intrinsic factors such as sex of individuals, as females may be able to retain less DHA in the brain due to the higher investment of $n-3$ LC-PUFA to gametes (Maklakov 2008; Hou \& Fuiman 2020). The capacity to synthetize and retain DHA has also been shown to decrease over ontogeny in freshwater fishes (Chaguaceda et al. 2020) and mammals (Brenna 2011). A good example of the energetic trade-off linked to the synthesis of $n-3$ LCPUFA from dietary sources of different quality are consumers that depend on a mix of prey from aquatic and terrestrial resources (Twining et al., 2019). Aquatic and terrestrial macroinvertebrates are reciprocal sources of energy and macronutrients (Nakano \& Mukarami 2001; Sullivan et al. 2014), but aquatic macroinvertebrates provide substantially more long-chain EPA than terrestrial macroinvertebrates, which contain mainly short-chain ALA (Guo et al. 2018; Brett et al. 2019). Predominantly insectivorous freshwater fishes, such as stream salmonids, depend on macroinvertebrates from aquatic and terrestrial subsidies (Nakano \& Mukarami 2001; Syrjänen et al. 2011; Sánchez-Hernández \& Cobo 2018). Therefore, intra-specific dietary specialization and intrinsic capacity to synthetize and retain n-3 LC-PUFA in a freshwater fishes could provide a first general insight in how these dietary biomolecules influence brain development of vertebrates in the wild.

In this study, we focus on brown trout Salmo trutta, a salmonid native to European streams, which is a generalist consumer displaying a broad range of dietary specialization among populations (SánchezHernández 2020) and individuals (Evangelista et al. 2014). We use a river system where brown trout cooccurs with the invasive brook trout Salvelinus fontinalis, as previous studies have shown that brown trout increases the consumption of terrestrial macroinvertebrates (i.e., low-quality prey deprived of n-3 LCPUFA) in sympatry with invasive brook trout (Závorka et al. 2017; Cucherousset et al. 2020; but see Horká et al. 2017). Therefore, this study system allows us to test an entirely natural setting how reduced dietary intake of n-3 LC-PUFA influence the physiology and brain development of wild consumers. We explore how dietary reliance on terrestrial prey affects brain size and brain morphology of brown trout in sympatry and allopatry with the invasive brook trout, while accounting for ontogenetic and sex differences among individuals. We predict that; $I$ ) higher reliance on terrestrial prey of brown trout reduces 
dietary intake of EPA; ii) the content of EPA and DHA in brown trout tissues decreases with increasing reliance on terrestrial prey; and iii) lower DHA content in brown trout tissues is associated with smaller brain size or changes in brain morphology (i.e., region specific brain size reduction).

\section{Material And Methods}

\section{Study sites and fish sampling}

This study was conducted in three streams in the upper part of the catchment of the Viskan River,

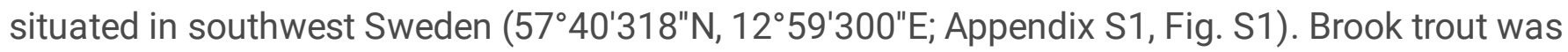
introduced to Sweden in 1892 (Aas et al. 2018), with the first electrofishing reports indicating a selfreproducing brook trout population in our study system dating to 1985 (SERS, 2013). While brook trout have occurred in European streams for over a century, its impact on the native species is still significant and it is recognized by many European countries including Sweden as an invasive alien species (e.g., Strand et al. 2018). Populations of brook trout are established in the upstream sections of the sampled streams. Native brown trout occupy the whole system, and thus each stream contains an allopatric (brown trout only) and a sympatric (brown and brook trout co-occurring) section. The brown trout populations in the study stream are landlocked with no reported lake or seawards migration. Abundance of brown and brook trout in the studied streams ranges from $0.2-1$ individual per meter of the stream length. At sympatric sites, brook trout is as abundant or more abundant than brown trout (Závorka et al. 2017). Other fish species occurring in the study system are brook lamprey Lamperta planeri, common minnow Phoxinus phoxinus, and occasionally northern pike Esox lucius.

Experimental fish were collected by electrofishing (LR-20B; Smith-Root, Vancouver, WA, USA) carried out over a $500 \mathrm{~m}$ stretch at each study site (Appendix S1, Table S1) between May 11 and June 11, 2019 (Appendix S1, Table S1). All sampled brown trout were measured (fork length i.e., from the tip of the snout to the end of the central caudal fin ray) and a small clip of the pelvic fin $\left(\sim 0.5 \mathrm{~cm}^{2}\right)$ was stored on ice and later in laboratory kept in freezer at $-80^{\circ} \mathrm{C}$, awaiting stable isotope analysis. We have collected between 38 to 45 brown trout per sampling site with average fork length ranging from 93 to $143 \mathrm{~mm}$ (Appendix S1). Aquatic macroinvertebrates for fatty acid and bulk stable isotope analysis were collected using kick sampling and terrestrial macroinvertebrates were collected by hand-picking and dragging the kick net over the canopy surrounding the stream. The macroinvertebrate samples were collected at each sampling site the same day as the fish and were stored alive in an icebox and after determination in the laboratory kept frozen at $-80^{\circ} \mathrm{C}$ until further processing. Habitat quality was evaluated at each study site on July 10, 2019 using standardized protocol (Jönköpingsmodellen - Halldén et al. 2002, Appendix S1, Table S1) and photographs of habitats at each sampling site were taken (Appendix S1, Fig. S1).

Consumption of aquatic macroinvertebrates by brown trout is known to increase with their abundance in the stream (Evangelista et al. 2014; Sánchez-Hernández \& Cobo 2018). Therefore, we performed a quantitative assessment of abundance and biomass of aquatic macroinvertebrates at each sampling site on July 11 and 12, 2019 during sunny stable weather, with no precipitation and low water flow. Aquatic 
macroinvertebrates were collected by a kick-net $(30 \times 25 \mathrm{~cm}$, mesh size, 30 seconds of kicking at three spots within each study site representing all available habitats). Macroinvertebrates were counted and oven-dried at $60^{\circ} \mathrm{C}$ for 48 hours and total dry biomass of macroinvertebrates at each sampling site was measured to the nearest $0.001 \mathrm{~g}$ (Appendix S1, Table S1).

\section{Fish dissection}

A subsample of brown trout (Table 1) at each study site was transported alive to the department of Biology and Environmental Sciences at the University of Gothenburg for dissection. Before the dissection, fish were housed in holding tanks ( $30 \mathrm{~L}, 300 \times 320 \times 340 \mathrm{~mm}$ ), which provided shelter structures (rocks and plastic plants) and fresh $12^{\circ} \mathrm{C}$ water from a flow-through filtration system (flow rate: $2 \mathrm{~L} \mathrm{~min}^{-1}$ ). Fish were not fed during this period. All fish were dissected within 20 hours after capture and to randomize the time effect, individuals from allopatric and sympatric sites were dissected in alternating order (with even

and odd individuals from allopatry and sympatry respectively). Before dissection, fish were euthanized by an overdose of 2-phenoxyethanol $\left(0.5 \mathrm{~mL} \mathrm{~L}^{-1}\right)$ and body mass and fork length were measured to the nearest $0.1 \mathrm{~g}$ and $1.0 \mathrm{~mm}$ respectively. Sex of individuals was determined by inspection of the gonads. Heads of fish were removed and fixed in $4 \%$ buffered ( $\mathrm{pH} \mathrm{6.9)}$ paraformaldehyde solution. Brains were then dissected out as described in Gonda et al. (2009) by opening the scull along the anteroposterior axis and removing muscle tissue, nerves and bones until the brain could be lifted up from the skull and stored in $4 \%$ buffered paraformaldehyde solution until further procedure. Brains were imaged with a digital camera (EOS 40D with MP-E 65mm lens; Canon Inc., Tokyo, Japan). Images of brains were taken using the dorsal, left lateral and ventral views to calculate the total volume and the volume of cerebellum, optic tectum, telencephalon, olfactory bulb, and hypothalamus. Measurements were completed using ImageJ 1.48 (Schneider et al. 2021) and used to calculate volume with the formulas outlined by Pollen et al. (2007). Brain morphology was assessed by principal component analysis (Appendix S2) yielding two dominant principal components. PC1 was positively related to the volume of olfactory bulb, and hypothalamus and negatively related to cerebellum and optic tectum, while PC2 was positively related to the volume of telencephalon.

Fixing fish brains in paraformaldehyde solution in order to do morphological measurements prevented us from performing fatty acid analysis of the brain tissue. Therefore, we have used the muscle tissue as a proxy of n-3 LC-PUFA content in fish body. Muscles provide a good proxy for this purpose, because they represent the majority of fish biomass, and thus muscle metabolic activity and fatty acids content reflects individuals as a whole (Norin \& Malte 2012; Gladyshev et al. 2018). In addition, biochemical composition of muscle tissue of salmonids has been shown to respond in similar direction to dietary deprivation of $\mathrm{n}$ 3 LC-PUFA as brain tissue, but with higher magnitude (Závorka et al. 2021). Thus, samples $(\sim 1 \mathrm{~g}$ of wet mass) of dorsal and ventral muscle tissue samples were taken from the left side below the dorsal fin, above and below the lateral line respectively. Bones and skin residuals were mechanically removed from the tissue samples, before they were stored on dry ice and subsequently frozen at $-80^{\circ} \mathrm{C}$.

\section{Bulk stable isotope and fatty acids analysis}


We used bulk tissue analyses of $\delta^{13} \mathrm{C}$ fin clips and potential prey to estimate diet composition of experimental individuals. Freeze-dried and homogenized samples were analysed in WasserCluster Lunz, Austria. Isotope ratios are reported relative to the international Vienna PeeDee Belemnite carbonate standard. $\delta^{13} \mathrm{C}$ values were mathematically corrected for lipid content following methods as described by Post et al. (2007). The baseline ${ }^{13} \mathrm{C}$ value was further corrected to account for variability in basal resources across the sampling sites (Olsson et al. 2009; Musseau et al. 2020) using the following equation:

$$
\delta^{13} C_{\text {corri }}=\frac{\delta^{13} C_{i}-\delta^{13} C_{i n v}}{C R_{\text {inv }}}
$$

where $\delta^{13} \mathrm{C}_{\text {corr } i}$ is the corrected carbon isotopic ratio for individual $i, \delta^{13} \mathrm{C} i$ is the carbon isotopic ratio for individual $i, \delta^{13} \mathrm{C}_{i n v}$ is the average carbon isotope ratio of macroinvertebrates and $\mathrm{CR}_{\mathrm{inv}}$ is the carbon range $\left(\delta^{13} \mathrm{C}_{\text {max }}-\delta^{13} \mathrm{C}_{\text {min }}\right)$ of macroinvertebrates. $\delta^{13} \mathrm{C}_{\text {corr } i}$ is hereafter used as an indicator of reliance on terrestrial prey (i.e., increasing value suggests increasing reliance of an individual on terrestrial prey).

Fatty acids were extracted and analysed from freeze-dried samples (3-10 mg dry mass) that were homogenized, sonicated and vortexed (4 times) in a chloroform-methanol (2:1) mixture, following Böhm et al. (2014). Total lipid mass ratios were determined via gravimetry. Fatty acids were derivatized to obtain fatty acid methyl esters (FAME) using toluene and sulfuric acid-methanol-solution (incubated at 16 $h$ at $50 \mathrm{C}$ ). FAME were identified using a gas chromatograph (Thermo Scientific TRACE GC Ultra) equipped with a flame ionization detector (FID) and a Supelco SP-2560 column (100 m, $25 \mathrm{~mm}$ i.d., 0.2 $\mu \mathrm{m}$ film thickness). Quantification of fatty acids were performed by comparison with a known concentration of the internal standard using Excalibur 1.4 (Thermo Electron Corporation).

\section{Statistical analysis}

All analyses were conducted in R v4.0.2 (http://www.R-project.org/). The structure of the final linear models and sample sizes break down by the levels of categorical explanatory variables are summarized in (Appendix S3). Non-significant interactions were removed from the models. Significance of the final models was evaluated using ANOVA tables using Type II and III sums of squares for models without and with significant interaction, respectively. Differences among groups were analysed using Tukey's HSD post-hoc test. We have accounted for the ontogenetic effects by using fork length as a proxy of individuals age. Fork length has been used as explanatory variable in all models. When models contained other explanatory variables correlated to the fork length, we used residuals from a linear model between the log transformed variable of interest and fork length to prevent collinearity (see Appendix S3).

We tested the variability in content of ALA and EPA, and of total lipids in macroinvertebrates across all sampling sites (i.e., category with 6 levels -3 streams $\cdot 2$ populations [allopatric, sympatric]) and subsidy types (category with 2 levels - aquatic or terrestrial macroinvertebrates). Since there was no difference lipid quality of aquatic and terrestrial subsidies across the six sampling sites (see results for details), we 
did not include the stream or sampling site in the models. We collected samples of dorsal and ventral muscle tissue because concentration of adipose cells is usually higher in ventral than in dorsal muscles and thus these two tissues can differ in their lipid content (Fauconneau et al. 1995; Ebm et al. 2021). However, the total lipid content and the relative content of n-3 LC-PUFA were repeatable across dorsal and ventral muscle samples (total lipids: $R_{a d j}=0.25,95 \% \mathrm{Cl}[0.06,0.44]$; ALA: $R_{\text {adj }}=0.59,95 \% \mathrm{Cl}[0.44,0.72]$; EPA: $R_{a d j}=0.62,95 \% \mathrm{Cl}[0.48,0.74] ; \mathrm{DHA}: \mathrm{R}_{\mathrm{adj}}=0.56,95 \% \mathrm{Cl}[0.41,0.70]$. Therefore, for further analysis we have used an average value across tissues for each individual. Total lipids in all models were reported as mass fractions ( $\mathrm{mg} / \mathrm{g}$ of the dry mass), while all models and figures including n-3 LC-PUFA reported the relative fatty acid contents (\% of fatty acid methyl esters; with exception of Fig. 1). This is a common approach (e.g., Twining et al. 2019; Ebm et al. 2021) because mass fractions of fatty acids are often closely correlated to the total lipid mass fractions, while the relative content of fatty acids is independent of the total lipids and thus more comparable across the sample types and studies, particularly when only a part of an organism (e.g., muscle tissues) is analysed.

\section{Results}

Reliance on terrestrial prey was higher in sympatric than in allopatric brown trout $\left(F_{1 ; 161}=52.67, p<\right.$ 0.001 ; Fig. 1). The reliance on terrestrial prey also increased with increasing body size $\left(F_{1 ; 161}=98.26, p<\right.$ $0.001)$, but it did not differ between the sexes $\left(F_{1 ; 79}=0.01, p=0.911 ;\right.$ Fig. 1$)$. Reliance on terrestrial prey increased with increasing abundance $\left(F_{1 ; 161}=120.01, p<0.001\right)$ and biomass $\left(F_{1 ; 161}=63.06, p<0.001\right)$ of aquatic macroinvertebrates at the sampling site. This indicates that the consumption of aquatic and terrestrial prey by brown trout was not limited by the availability of aquatic prey in the stream, but abundance and biomass of aquatic macroinvertebrates appeared to be controlled by the foraging behaviour of brown trout.

Terrestrial macroinvertebrates contained on average less total lipids (mean $\pm S D=148 \pm 69 \mathrm{mg} / \mathrm{dry}$ mass) than aquatic prey macroinvertebrates (mean $\pm S D=204 \pm 86 \mathrm{mg} / \mathrm{g}$ dry mass; $F_{1 ; 51}=8.93, p=0.004$ ).

Terrestrial macroinvertebrates had similar content of $\operatorname{ALA}\left(F_{1 ; 51}=1.39, p=0.245\right)$ and significantly lower $\operatorname{EPA}\left(\mathrm{F}_{1 ; 51}=30.27, \mathrm{p}<0.001\right)$ than aquatic macroinvertebrates (Fig. 1a). Total lipids $\left(F_{5,55}=1.70, p=\right.$ $0.151)$, and the content of ALA $\left(F_{5,55}=0.40, p=0.845\right)$ and EPA $\left(F_{5,55}=1.00, p=0.42\right)$ of macroinvertebrates did not differ across the sampling sites. Aquatic macroinvertebrates were thus a richer dietary source of n-3 LC-PUFA, particularly of EPA, than terrestrial macroinvertebrates across all sampling sites (Fig. 1a).

The content of total lipids in brown trout tissues did not differ between sympatric and allopatric populations $\left(F_{1,80}=0.06, p=0.803\right)$ and was not significantly related to the reliance on terrestrial prey $\left(F_{1,80}=0.02, p=0.890\right)$, fork length $\left(F_{1,80}=2.23, p=0.139\right)$, and $\operatorname{sex}\left(F_{1,80}=0.07, p=0.789\right)$ of individuals. The ALA content in trout tissues was affected by an interaction between the competition mode and reliance on terrestrial prey $\left(F_{1,79}=5.71, p=0.019 ; \mathrm{Fig} .1 \mathrm{~b}\right)$, so ALA increased with increasing reliance on terrestrial prey in sympatric $\left(F_{1,39}=8.74, p=0.005\right)$, but not in allopatric $\left(F_{1,38}=0.73, p=\right.$ 
$0.397)$ brown trout. Sex $\left(F_{1,79}=0.52, p=0.472\right)$ and body length $\left(F_{1,79}=3.14, p=0.080\right)$ had no significant effect on ALA content in trout tissues. The EPA content was higher in allopatric than in sympatric brown trout $\left(F_{1,80}=14.29, p<0.001\right.$; Fig. $\left.1 c\right)$ and decreased with increasing fork length $\left(F_{1,80}=\right.$ $146.89, p=0.001)$, but was not affected by individual's $\operatorname{sex}\left(F_{1,80}=0.28, p=0.597\right)$ and reliance on terrestrial prey $\left(F_{1,80}=0.87, p=0.353\right)$. The DHA content in trout tissues was affected by an interaction between the competition mode and reliance on terrestrial prey $\left(F_{1,78}=7.46, p=0.007\right.$; Fig. $\left.1 d\right)$, so DHA decreased with increasing reliance on terrestrial prey in sympatric $\left(F_{1,38}=7.14, p=0.011\right)$, but not in allopatric $\left(F_{1,38}=1.07, p=0.307\right)$ populations. Sex had no effect on DHA in trout tissues $\left(F_{1,78}=0.74, p=\right.$ $0.391)$, but DHA content decreased with increasing body size $\left(F_{1,78}=6.33, p=0.014\right)$.

Brain volume increased with increasing DHA content in trout tissues $\left(F_{1,80}=11.57, p=0.001\right.$, Fig. $\left.2 a\right)$, but DHA content had no effect on brain morphology (PC 1: $F_{1,80}=0.92, p=0.341$, Fig. 2b; $P C 2: F_{1,80}=3.89, p$ $=0.052$, Fig. $2 \mathrm{c})$. Total lipids content in trout tissues had no significant effect on brain volume $\left(\mathrm{F}_{1,81}=\right.$ 2.92, $p=0.092)$ and morphology $\left(P C 1: F_{1,81}=1.27, p=0.263 ; P C 2: F_{1,81}=3.94, p=0.051\right)$. The brain volume increased with increasing fork length of individuals $\left(F_{1,80}=657.45, p<0.001\right)$, but brain morphology was independent of fork length ( $P C 1: F_{1,81}=0.07, p=0.786 ; P C 2: F_{1,80}=0.01, p=0.943$ ). Brain volume and brain morphology did not differ between allopatric and sympatric populations (brain volume: $F_{1,80}=0.51, p=0.476 ; P C 1: F_{1,80}=0.99, p=0.322 ; P C 2: F_{1,80}=0.00, p=0.990$ ) or between the sexes (brain volume: $F_{1,80}=1.54, p=0.219 ; P C 1: F_{1,81}=0.57, p=0.454 ; P C 2: F_{1,80}=0.05, p=0.943$ ).

\section{Discussion}

Dietary reliance of brown trout on low-quality terrestrial prey, deprived of n-3 LC-PUFA, increased in sympatry with invasive brook trout. Higher reliance on terrestrial prey of sympatric brown trout resulted in lower content of EPA in their muscle tissues compare to the allopatric conspecifics. In the sympatric populations, the content of the short-chain ALA increased and the content of the long-chain DHA decreased in muscle tissues with increasing reliance on the low-quality terrestrial prey, but the relative content of ALA and DHA in allopatric brown trout was not related to the diet quality. Sex had no effect on diet quality and muscle content of n-3 LC-PUFA, but larger (and presumably older, i.e., Bowker 1995; Öhlund et al. 2008) individuals relied more on terrestrial prey and consequently had lower relative content of $n-3$ LC-PUFA in muscles. We found that the relative content of DHA in muscle tissues was positively related to the encephalization of brown trout (i.e., higher relative brain size after controlling for the body size). These findings demonstrate that intra-specific differences in diet quality in wild vertebrates, foraging at interface of aquatic and terrestrial food webs, are linked to their brain size. In addition, our findings indicate that external stressors, such as competition with an invasive species, can reduce the capacity of consumers to synthetize and retain DHA for brain development.

Dietary intake and retention of energy in form of lipids has a substantial effect on the physiological development of consumers (Arts et al. 2009). However, our results indicate, in agreement with previous laboratory studies (Speake \& Wood 2005; Lund et al., 2012; Hall et al. 2014), that the availability of 
structural lipids, especially DHA, and not the lipid energy reserve is the key for brain development in vertebrate consumers. Our findings suggests that the specialization of dietary niche in wild consumers on resources that have similar content of energy, but differ in the content of n-3 LC-PUFA (Heissenberger et al. 2010; Twining et al. 2019; Scharnweber et a. 2021), can lead to intra-specific diversification of brain size. This is an important finding because brain size is positively correlated to cognitive capacity, especially among closely related species (Olkowicz et al. 2016) and at the intra-specific level (Møller 2010; Kotrschal et al. 2013). For example, guppies with larger brain size have shown higher learning capacity (Kotrschal et al. 2013), and large brain have been suggested to improve migration efficiency and offspring defence in barn swallows Hirundo rustica (Møller 2010). However, it should be noted that while dietary supply of omega-3 LC-PUFA is determinant for brain development of vertebrates (Pilecky et al. 2021), dietary availability of these biomolecules can also influence other phenotypic traits important for consumers fitness, such as mitochondrial efficiency (Salin et al. 2021; Závorka et al. 2021); metabolic rate (McKenzie 2001; Twining et al. 2016), growth rate (Chaguaceda et al. 2020; Závorka et al. 2021), and reproductive capacity (Brett et al. 2009; Scharnweber \& Gårdmark 2020). Therefore, further carefully designed experiments in a realistic ecological context are needed to understand the trajectory of how dietary omega-3 PUFA influences fitness of consumers in the wild.

Effects of diet quality on development of phenotypic traits necessarily depends on temporal scales on which the consumption of low- and high-quality diets occurs (Brett et al. 2009; Murray et al. 2014). For example, a relatively short-term study (i.e., 8 weeks of dietary treatment) by Závorka et al. (2021) on juvenile Atlantic salmon Salmo salar showed a strong shift of DHA content in the brain, but no significant effect on brain size and performance in a cognitive test. On the other hand, a longer study (i.e., 21 weeks of dietary treatment) by Lund et al. (2012) on juvenile pikeperch Sander luciperca demonstrated that dietary n-3 LC-PUFA deprivation induces leads to reductions of DHA content and size of the brain resulting in lower cognitive capacity. The reliance on terrestrial prey in our study was estimated based on bulk $\delta^{13} \mathrm{C}$ values of fin clips, which indicate dietary carbon on the temporal scale of several weeks (Jardine et al. 2005; Layman et al. 2012). However, a previous study has shown that the dietary shift of our focal species, brown trout, in sympatry with invasive brook trout occurs early in ontogeny and remains stable in later life-stages (Cucherousset et al., 2020). The increased reliance on low-quality terrestrial prey in our study did not appear to be influenced by the availability of aquatic prey, indicating that this dietary shift was likely caused by behavioural changes of brown trout in sympatry with the invasive species (Lovén Wallerius et al. 2017; Larranaga et al. 2018; Cucherousset et al., 2020). Thus, the intra-specific dietary differences in our study likely represent a long-term specialization of individuals that might have a permanent effect on supply of n-3 LC-PUFA to their brain.

Despite the higher reliance on low-quality terrestrial prey and corresponding decrease of EPA in muscle tissues, there was no significant reduction of DHA in muscles of sympatric compared to allopatric brown trout. A potential explanation is that sympatric brown trout has adapted to the lower dietary intake of n-3 LC-PUFA by increasing retention and/or internal synthesis of DHA (Murray et al. 2014). Such adaptation has been observed in populations of three-spined stickleback (Ishikawa et al., 2021) and European perch 
(Scharnweber et al., 2021) foraging on low-quality prey from littoral lake habitat that is deprived of n-3 LCPUFA. Similarly, tree swallows have been shown to increase synthesis of DHA when consuming n-3 LCPUFA deprived terrestrial macroinvertebrates (Twining et al., 2018). However, our results indicated limits of this adaptation as the relative content of DHA in sympatric trout decreased with increasing reliance on terrestrial prey. This suggests that the combination of external stressor (i.e., interaction with an invasive species) and high consumption of n-3 LC-PUFA deprived prey can affect the capacity of wild consumers to maintain an optimal biochemical composition of their tissues. Synthesis of DHA from short-chain precursors, such as ALA, contained in low-quality terrestrial diet comes at substantial energetic costs that can result in reduced somatic growth rate (Murray et al. 2014; Twining et al. 2016; 2018; Závorka et al. 2021). Our findings thus accentuate the suggestion that the trade-off between internal synthesis and dietary acquisition of n-3 LC-PUFA might be an important driver of phenotypic adaptations across vertebrate consumers (Twining et al. 2021). We also found that larger (and presumably older, i.e., Bowker 1995; Öhlund et al. 2008) individuals across populations relied more on terrestrial prey and had lower EPA and DHA contents in muscles. This age-dependent effect can be explained by the fact that older consumers require less n-3 LC-PUFA than younger consumers (Brenna 2011; Chaguaceda et al. 2020), because the key period of vertebrate brain development occurs during early ontogenetic stages (Innis 2007; Brenna 2011; Lund et al. 2012).

In conclusion, this field study demonstrates the largely overlooked importance of dietary intake of n-3 LCPUFA for brain development of wild vertebrate consumers, which have so far been recognized just under laboratory conditions (Pilecky et al. 2021). We have shown the link between n-3 LC-PUFA deprived diets and consumer's brain size in the context of competition with an invasive species. However, the ongoing global change is predicted to limit availability of n-3 LC-PUFA for vertebrate consumers on a large spatial scale (Hixson \& Arts, 2016; Heilpern et al. 2021) and it is still poorly understood how wild vertebrate consumers respond to this dietary deprivation of n-3 LC-PUFA. Our results indicate that it can have negative impacts even on species which are pre-adapted to dietary scarcity of these important biomolecules (i.e., salmonids often consume high proportion of low-quality terrestrial prey, Syrjänen et al. 2011; Evangelista et al. 2014). Dietary intake of n-3 LC-PUFA have a high potential to affect fitness of vertebrate consumers (Twining et al. 2021; Pilecky et al. 2021), and therefore further studies are needed to understand how the availability n-3 LC-PUFA in natural diets affects development of brain, behaviour, physiology and life-history of vertebrates.

\section{Declarations}

\section{Acknowledgements}

Authors are grateful to Samuel-Karl Kämmer, Katharina Winter, and Niklas Wengström for their assistance with collection and processing of samples.

Funding Study was funded by the Austrian Science Fund, FWF, Lise Meitner Program (Project M 2742BBL), Carl Tryggers foundation (CT 16:221). 
Conflicts of interest/Competing interests Authors have no conflict of interests to declare.

Ethics approval These experiments were approved by the Ethical Committee for Animal Research in Göteborg (license dnr 5.8.18-04106/2018) and comply with current laws in Sweden.

Availability of data and material Should the manuscript be accepted, all data will be archived at figshare.com (doi:).

Authors' contributions LZ, JH, MK conceived and designed the experiments. LZ and MLW performed the experiments with contribution of MK and JH. LZ analyzed the data. LZ wrote the manuscript; other authors provided editorial advice.

\section{References}

1. Aas $\varnothing$, Cucherousset J, Fleming IA, Wolter C, Höjesjö J, Buoro M, Arlinghaus R (2018) Salmonid stocking in five North Atlantic jurisdictions: Identifying drivers and barriers to policy change. Aquatic Conservation: Marine and Freshwater Ecosystems 28(6):1451-1464. https://doi.org/10.1002/aqc.2984

2. Araújo MS, Bolnick DI, Layman CA (2011) The ecological causes of individual specialisation. Ecol Lett 14(9):948-958. https://doi.org/10.1111/j.1461-0248.2011.01662.x

3. Arts MT, Brett MT, Kainz MJ (eds) (2009) Lipids in aquatic ecosystems. Springer Science \& Business Media

4. Baxter CV, Fausch KD, Murakami M, Chapman PL (2004) Fish invasion restructures stream and forest food webs by interrupting reciprocal prey subsidies. Ecology 85(10):2656-2663. https://doi.org/10.1890/04-138

5. Bowker DW (1995) Modelling the patterns of dispersion of length at age in teleost fishes. J Fish Biol 46(3):469-484

6. Boogert NJ, Madden JR, Morand-Ferron J, Thornton A (2018) Measuring and understanding individual differences in cognition. Philos Trans R Soc Lond, B, Biol Sci 373(1756):20170280. https://doi.org/10.1098/rstb.2017.0280

7. Böhm M, Schultz S, Koussoroplis AM, Kainz MJ (2014) Tissue-specific fatty acids response to different diets in common carp (Cyprinus carpio L.). PLoS ONE 9(4):e94759. https://doi.org/10.1371/journal.pone.0094759

8. Brenna JT (2011) Animal studies of the functional consequences of suboptimal polyunsaturated fatty acid status during pregnancy, lactation and early post-natal life. Matern Child Nutr 7:59-79

9. Brett MT, Kainz MJ, Taipale SJ, Seshan H (2009) Phytoplankton, not allochthonous carbon, sustains herbivorous zooplankton production. Proceedings of the National Academy of Sciences, 106(50), 21197-21201. https://doi.org/10.1073/pnas.0904129106

10. Brett MT, Bunn SE, Chandra S, Galloway AW, Guo F, Kainz MJ, Rasmussen JB (2017) How important are terrestrial organic carbon inputs for secondary production in freshwater ecosystems? Freshw Biol 
62(5):833-853. https://doi.org/10.1111/fwb.12909

11. Chaguaceda F, Eklöv P, Scharnweber K (2020) Regulation of fatty acid composition related to ontogenetic changes and niche differentiation of a common aquatic consumer. Oecologia 193:325336. https://doi.org/10.1007/s00442-020-04668-y

12. Cole NC, Harris S (2011) Environmentally-induced shifts in behavior intensify indirect competition by an invasive gecko in Mauritius. Biol Invasions 13(9):2063-2075. https://doi.org/10.1007/s10530011-0025-8

13. Cucherousset J, Závorka L, Ponsard S, Céréghino R, Santoul F (2020) Stable isotope niche convergence in coexisting native and non-native salmonids across age classes. Can J Fish Aquat Sci 77(8):1359-1365. https://doi.org/10.1139/cjfas-2019-0186

14. Ebm N, Guo F, Brett MT, Bunn SE, Kainz MJ (2021) Polyunsaturated fatty acids in fish tissues more closely resemble algal than terrestrial diet sources. Hydrobiologia 848(2).

https://doi.org/371-383

.. 10.1007/s10750-020-04445-1

15. Evangelista C, Boiche A, Lecerf A, Cucherousset J (2014) Ecological opportunities and intraspecific competition alter trophic niche specialization in an opportunistic stream predator. J Anim Ecol 83(5):1025-1034. https://doi.org/10.1111/1365-2656.12208

16. Fauconneau B, Andre S, Chmaitilly J, Le Bail PY, Krieg F, Kaushik SJ (1997) Control of skeletal muscle fibres and adipose cells size in the flesh of rainbow trout. J Fish Biol 50(2):296-314. https://doi.org/10.1111/j.1095-8649.1997.tb01360.x

17. Gladyshev MI, Sushchik NN, Tolomeev AP, Dgebuadze YY (2018) Meta-analysis of factors associated with omega-3 fatty acid contents of wild fish. Rev Fish Biol Fish 28(2):277-299. https://doi.org/10.1007/s11160-017-9511-0

18. Graham SP, Freidenfelds NA, Thawley CJ, Robbins TR, Langkilde T (2017) Are invasive species stressful? The glucocorticoid profile of native lizards exposed to invasive fire ants depends on the context. Physiol Biochem Zool 90(3):328-337. https://doi.org/10.1086/689983

19. Gonda A, Herczeg G, Merilä J (2009) Adaptive brain size divergence in nine-spined sticklebacks (Pungitius pungitius)? J Evol Biol 22(8):1721-1726. https://doi.org/10.1111/j.14209101.2009.01782.x

20. Guo F, Bunn SE, Brett MT, Fry B, Hager H, Ouyang X, Kainz MJ (2018) Feeding strategies for the acquisition of high-quality food sources in stream macroinvertebrates: Collecting, integrating, and mixed feeding. Limnol Oceanogr 63(5):1964-1978. https://doi.org/10.1002/Ino.10818

21. Guo F, Ebm N, Bunn SE, Brett MT, Hager H, Kainz MJ (2021) Longitudinal variation in the nutritional quality of basal food sources and its effect on invertebrates and fish in subalpine rivers. $J$ Anim Ecol. https://doi.org/10.1111/1365-2656.13574

22. Hall ZJ, Bauchinger U, Gerson AR, Price ER, Langlois LA, Boyles M, Pierce B, McWilliams SR, Sherry DF, MacDougall-Shackleton SA (2014) Site-specific regulation of adult neurogenesis by dietary fatty 
acid content, vitamin E and flight exercise in European starlings. Eur J Neurosci 39:875-882. https://doi.org/10.1111/ejn.12456

23. Halldén A, Liliegren Y, Lagerkvist G (2002) Biotopkartering vattendrag-Metodik för kartering av biotoper i och i anslutning till vattendrag. Länsstyrelsen i Jönköpings län

24. Han CS, Dingemanse NJ (2015) Effect of diet on the structure of animal personality. Frontiers in Zoology 12(S1). S5. https://doi.org/10.1186/1742-9994-12-S1-S5

25. Heilpern SA, DeFries R, Fiorella K, Flecker A, Sethi SA, Uriarte M, Naeem S (2021) Declining diversity of wild-caught species puts dietary nutrient supplies at risk. Sci Adv 7(22):eabf9967

26. Heissenberger M, Watzke J, Kainz MJ (2010) Effect of nutrition on fatty acid profiles of riverine, lacustrine, and aquaculture-raised salmonids of pre-alpine habitats. Hydrobiologia 650(1):243-254. https://doi.org/10.1007/s10750-010-0266-z

27. Hixson SM, Arts MT (2016) Climate warming is predicted to reduce omega-3, long-chain, polyunsaturated fatty acid production in phytoplankton. Glob Change Biol 22(8):2744-2755. https://doi.org/10.1111/gcb.13295

28. Horká P, Sychrová O, Horký P, Slavík O, Švátora M, Petrusek A (2017)

29. Feeding habits of the alien brooktrout Salvelinus fontinalis and the native

30. brown trout Salmo trutta in Czech mountain streams.KMAE418:6. https://doi.org/10.1051/kmae/2016038

31. Hou Z, Fuiman LA (2020) Nutritional programming in fishes: insights from mammalian studies. Rev Fish Biol Fish 30(1):67-92. https://doi.org/10.1007/s11160-019-09590-y

32. Innis SM (2007) Dietary (n-3) Fatty Acids and Brain Development. J Nutr 137(4):855-859. https://doi.org/10.1093/jn/137.4.855

33. Ishikawa A, Stuart YE, Bolnick DI, Kitano J (2021) Copy number variation of a fatty acid desaturase gene Fads2 associated with ecological divergence in freshwater stickleback populations. Biol Lett 17(8):20210204

34. Ishizaki Y, Masuda R, Uematsu K, Shimizu K, Arimoto M, Takeuchi T (2001) The effect of dietary docosahexaenoic acid on schooling behaviour and brain development in larval yellowtail. J Fish Biol 58:1691-1703. https://doi.org/10.1111/j.1095-8649.2001.tb02323.x

35. Jardine TD, Gray MA, McWilliam SM, Cunjak RA (2005) Stable isotope variability in tissues of temperate stream fishes. Trans Am Fish Soc 134(5):1103-1110. https://doi.org/10.1577/T04-124.1

36. Jonsson N, Jonsson B (1997) Energy allocation in polymorphic Brown Trout. Funct Ecol 11:310317. https://doi.org/10.1046/j.1365-2435.1997.00083.x

37. Kawakita E, Hashimoto M, Shido O (2006) Docosahexaenoic acid promotes neurogenesis in vitro and in vivo. Neuroscience 139(3):991-997

38. Kotrschal A, Rogell B, Bundsen A, Svensson B, Zajitschek S, Brännström I, Kolm N (2013) Artificial selection on relative brain size in the guppy reveals costs and benefits of evolving a larger brain. Curr Biol 23(2):168-171. https://doi.org/10.1016/j.cub.2012.11.058 
39. Larranaga N, Wallerius ML, Guo H, Cucherousset J, Johnsson JI (2019) Invasive brook trout disrupt the diel activity and aggregation patterns of native brown trout. Can J Fish Aquat Sci 76(7):10521059. https://doi.org/10.1139/cjfas-2018-0110

40. Layman CA, Araujo MS, Boucek R, Hammerschlag-Peyer CM, Harrison E, Jud ZR, Bearhop S (2012) Applying stable isotopes to examine food-web structure: an overview of analytical tools. Biol Rev 87(3):545-562. https://doi.org/10.1111/j.1469-185X.2011.00208.x

41. Lovén Wallerius M, Näslund J, Koeck B, Johnsson JI (2017) Interspecific association of brown trout (Salmo trutta) with non-native brook trout (Salvelinus fontinalis) at the fry stage. Ethology 123(12):933-941. https://doi.org/10.1111/eth.12692

42. Lund I, Skov PV, Hansen BW (2012) Dietary supplementation of essential fatty acids in larval pikeperch (Sander lucioperca); short and long term effects on stress tolerance and metabolic physiology. Comp Biochem Physiol A: Mol Integr Physiol 162(4):340-348. https://doi.org/10.1016/j.cbpa.2012.04.004

43. Lund I, Höglund E, Ebbesson LO, Skov PV (2014) Dietary LC-PUFA deficiency early in ontogeny induces behavioural changes in pike perch (Sander lucioperca) larvae and fry. Aquaculture 432:453461. https://doi.org/10.1016/j.aquaculture.2014.05.039

44. Maklakov AA, Simpson SJ, Zajitschek F, Hall MD, Dessmann J, Clissold F, Brooks RC (2008) Sexspecific fitness effects of nutrient intake on reproduction and lifespan. Curr Biol 18(14):1062-1066. https://doi.org/10.1016/j.cub.2008.06.059

45. Marzetz V, Koussoroplis AM, Martin-Creuzburg D, Striebel M, Wacker A (2017) Linking primary producer diversity and food quality effects on herbivores: a biochemical perspective. Sci Rep 7(1):19. https://doi.org/10.1038/s41598-017-11183-3

46. McKenzie DJ (2001) Effects of dietary fatty acids on the respiratory and cardiovascular physiology of fish. Comp Biochem Physiol A: Mol Integr Physiol 128(3):605-619. https://doi.org/10.1016/S1095-6433(00)00338-X

47. Møller AP (2010) Brain size, head size and behaviour of a passerine bird. J Evol Biol 23(3):625-635. https://doi.org/10.1111/j.1420-9101.2009.01928.x

48. Murray DS, Hager H, Tocher DR, Kainz MJ (2014) Effect of partial replacement of dietary fish meal and oil by pumpkin kernel cake and rapeseed oil on fatty acid composition and metabolism in Arctic charr (Salvelinus alpinus). Aquaculture 431:85-91. https://doi.org/10.1016/j.aquaculture.2014.03.039

49. Musseau C, Vincenzi S, Santoul F, Boulêtreau S, Jesenšek D, Crivelli AJ (2020) Within-individual trophic variability drives short-term intraspecific trait variation in natural populations. J Anim Ecol 89(3):921-932. https://doi.org/10.1111/1365-2656.13149

50. Nakano S, Murakami M (2001) Reciprocal subsidies: dynamic interdependence between terrestrial and aquatic food webs. Proceedings of the National Academy of Sciences, 98(1), 166-170. https://doi.org/10.1073/pnas.98.1.166 
51. Näslund J, Aldvén D, Závorka L (2015) Eggs from anadromous adults provide marine-derived nutrients to Atlantic salmon and brown trout parr in late autumn-observations from a Swedish coastal stream. Environ Biol Fish 98(12):2305-2313. https://doi.org/10.1007/s10641-015-0436-y

52. Nevoux M, Finstad B, Davidsen JG, Finlay R, Josset Q, Poole R, Jonsson B (2019) Environmental influences on life history strategies in partially anadromous brown trout (Salmo trutta, Salmonidae). Fish Fish 20(6):1051-1082. https://doi.org/10.1111/faf.12396

53. Norin T, Malte H (2012) Intraspecific variation in aerobic metabolic rate of fish: relations with organ size and enzyme activity in brown trout. Physiol Biochem Zool 85:645-656. https://doi.org/10.1086/665982

54. Olsson K, Stenroth P, Nyström PER, Graneli W (2009) Invasions and niche width: does niche width of an introduced crayfish differ from a native crayfish? Freshw Biol 54(8):1731-1740. https://doi.org/10.1111/j.1365-2427.2009.02221.x

55. Olkowicz S, Kocourek M, Lučan RK, Porteš M, Fitch WT, Herculano-Houzel S, Němec $P$ (2016) Birds have primate-like numbers of neurons in the forebrain. Proceedings of the National Academy of Sciences, 113(26), 7255-7260

56. Öhlund G, Nordwall F, Degerman E, Eriksson T (2008) Life history and large-scale habitat use of brown trout (Salmo trutta) and brook trout (Salvelinus fontinalis)-implications for species replacement patterns. Can J Fish Aquat Sci 65(4):633-644. https://doi.org/10.1139/f08-003

57. Pilecky M, Závorka L, Arts MT, Kainz MJ (2021) Omega-3 PUFA profoundly affect neural, physiological, and behavioural competences - implications for systemic changes in trophic interactions. Biol Rev. https://doi.org/10.1111/brv.12747

58. Pollen AA, Dobberfuhl AP, Scace J, Igulu MM, Renn SC, Shumway CA, Hofmann HA (2007) Environmental complexity and social organization sculpt the brain in Lake Tanganyikan cichlid fish. Brain Behav Evol 70(1):21-39. https://doi.org/10.1159/000101067

59. Post DM, Layman CA, Arrington DA, Takimoto G, Quattrochi J, Montana CG (2007) Getting to the fat of the matter: models, methods and assumptions for dealing with lipids in stable isotope analyses. Oecologia 152(1):179-189. https://doi.org/10.1007/s00442-006-0630-x

60. Salin K, Mathieu-Resuge M, Graziano N, Dubillot E, Le Grand F, Soudant P, Vagner M (2021) The relationship between membrane fatty acid content and mitochondrial efficiency differs within-and between-omega-3 dietary treatments. Mar Environ Res 163:105205. https://doi.org/10.1016/j.marenvres.2020.105205

61. Sánchez-Hernández J, Cobo F (2018) Examining the link between dietary specialization and foraging modes of stream-dwelling brown trout Salmo trutta. J Fish Biol 93(1):143-146

62. Sánchez-Hernández J (2020) Drivers of piscivory in a globally distributed aquatic predator (brown trout): a meta-analysis. Sci Rep 10(1):1-10. https://doi.org/10.1038/s41598-020-68207-8

63. Schneider CA, Rasband WS, Eliceiri KW (2021) NIH Image to ImageJ: 25 years of image analysis. Nat Methods 9:671-675. doi: 10.1038/nmeth.2089) 
64. Scharnweber K, Chaguaceda F, Eklöv P (2021) Fatty acid accumulation in feeding types of a natural freshwater fish population. Oecologia 196:53-63. https://doi.org/10.1007/s00442-021-04913-y

65. Scharnweber K, Gårdmark A (2020) Feeding specialists on fatty acid-rich prey have higher gonad weights: Pay-off in Baltic perch? Ecosphere 11(8):e03234. https://doi.org/10.1002/ecs2.3234

66. Speake BK, Wood NA (2005) Timing of incorporation of docosahexaenoic acid into brain and muscle phospholipids during precocial and altricial modes of avian development. Comp Biochem Physiol B: Biochem Mol Biol 141(2):147-158. https://doi.org/10.1016/j.cbpc.2005.02.009

67. Strand M, Aronsson M, Svensson M (2018) Klassificering av främmande arters effekter på biologisk mångfald i Sverige - ArtDatabankens risklista. ArtDatabanken Rapporterar 21

68. Sugasini D, Thomas R, Yalagala PC, Tai LM, Subbaiah PV (2017) Dietary docosahexaenoic acid (DHA) as lysophosphatidylcholine, but not as free acid, enriches brain DHA and improves memory in adult mice. Sci Rep 7(1):1-11. https://doi.org/10.1038/s41598-017-11766-0

69. Syrjänen J, Korsu K, Louhi P, Paavola R, Muotka T (2011) Stream salmonids as opportunistic foragers: the importance of terrestrial invertebrates along a stream-size gradient. Can J Fish Aquat Sci 68(12):2146-2156. https://doi.org/10.1139/f2011-118

70. Sullivan ML, Zhang Y, Bonner TH (2014) Carbon and nitrogen ratios of aquatic and terrestrial prey for freshwater fishes. J Freshw Ecol 29(2):259-266. https://doi.org/10.1080/02705060.2014.888524

71. Twining CW, Brenna JT, Lawrence P, Shipley JR, Tollefson TN, Winkler DW (2016a) Omega-3 longchain polyunsaturated fatty acids support aerial insectivore performance more than food quantity. Proceedings of the National Academy of Sciences, 113(39), 10920-10925. https://doi.org/10.1073/pnas.1603998113

72. Twining CW, Lawrence P, Winkler DW, Flecker AS, Brenna JT (2018) Conversion efficiency of alinolenic acid to omega-3 highly unsaturated fatty acids in aerial insectivore chicks. J Exp Biol 221(3):jeb165373. https://doi.org/10.1242/jeb.165373

73. Twining CW, Brenna JT, Lawrence P, Winkler DW, Flecker AS, Hairston NG Jr (2019) Aquatic and terrestrial resources are not nutritionally reciprocal for consumers. Funct Ecol 33(10):2042-2052. https://doi.org/10.1111/1365-2435.13401

74. Twining CW, Bernhardt JR, Derry AM, Hudson CM, Ishikawa A, Kabeya N, Kainz MJ, Kitano J, Kowarik C, Ladd SN, Leal MC, Scharnweber K, Shipley JR, Matthews B (2021) The evolutionary ecology of fatty-acid variation: Implications for consumer adaptation and diversification. Ecol Lett. https://doi.org/10.1111/ele.13771

75. Závorka L, Koeck B, Cucherousset J, Brijs J, Näslund J, Aldvén D, Johnsson JI (2017) Co-existence with non-native brook trout breaks down the integration of phenotypic traits in brown trout parr. Funct Ecol 31(8):1582-1591. https://doi.org/10.1111/1365-2435.12862

76. Závorka L, Crespel A, Dawson NJ, Papatheodoulou M, Killen SS, Kainz MJ (2021) Climate change induced deprivation of dietary essential fatty acids can reduce growth and mitochondrial efficiency of wild juvenile salmon. Funct Ecol. https://doi.org/10.1111/1365-2435.13860 


\section{Figures}

(A)

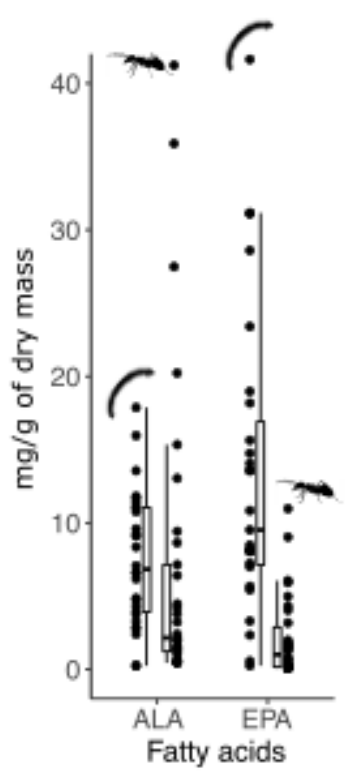

(C)
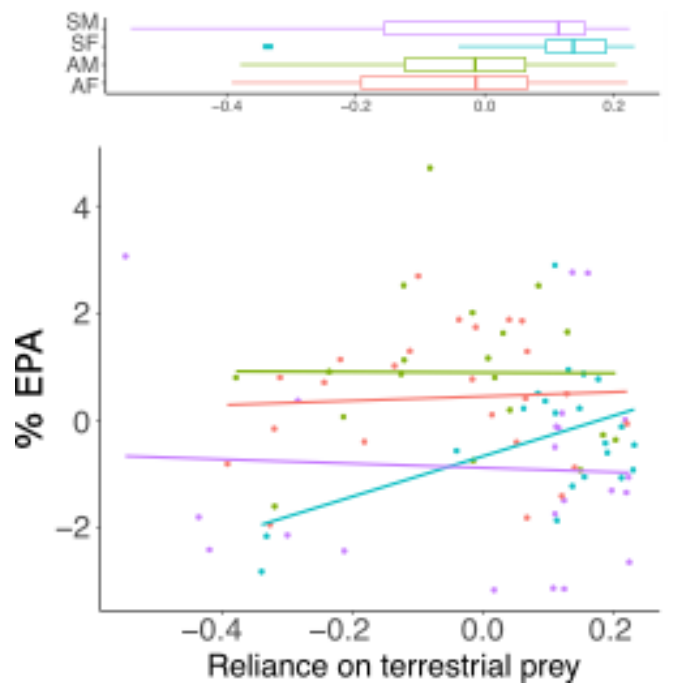

(B)
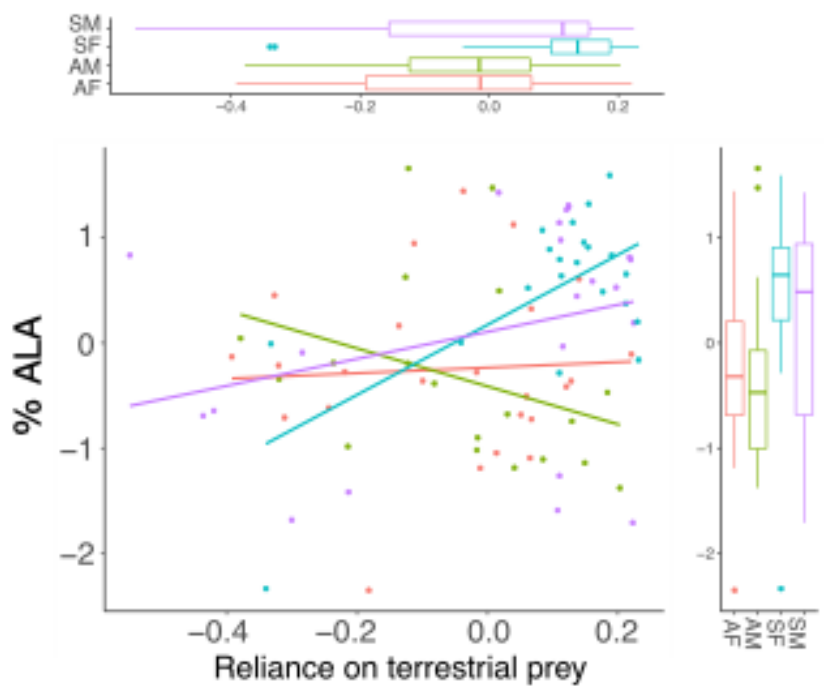

(D)
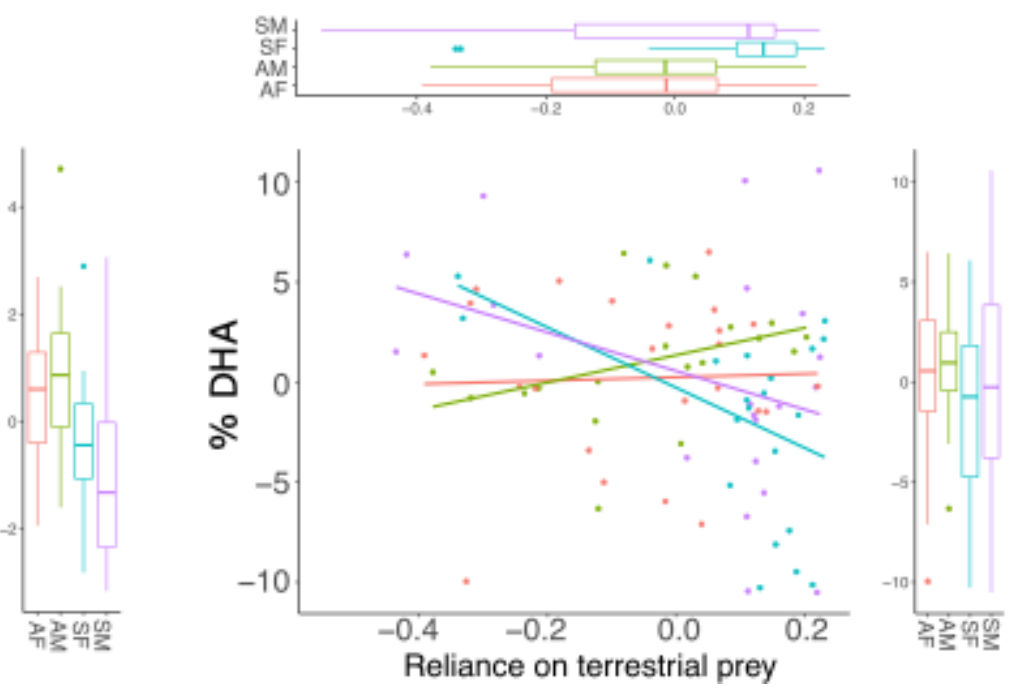

Figure 1

(a) Content $\mathrm{mg} / \mathrm{g}$ of ALA and EPA in aquatic and terrestrial prey macroinvertebrates. All prey samples contained no or negligible amount of DHA. Association of the reliance on terrestrial prey and the relative content of ALA (b), EPA (c), and DHA (d) in trout tissues. Colours of datapoints, fit lines and box plots displaying distribution of each variable correspond to AF - allopatric females (red), AM - allopatric males (green), SF - sympatric females (cyan), and SM - sympatric males (purple). Variables in figures b-d are residuals controlled for the fork length of individuals. 


\section{(A)}
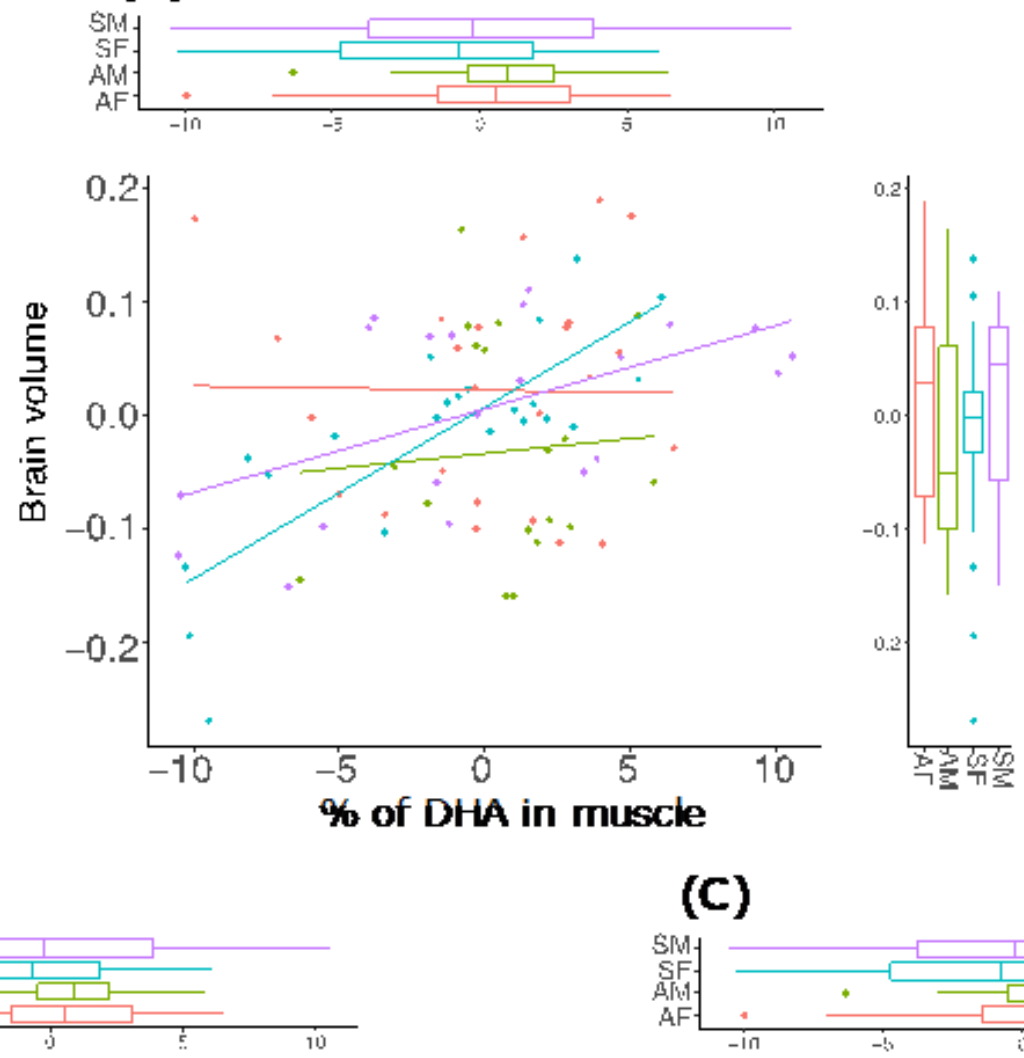

(B)
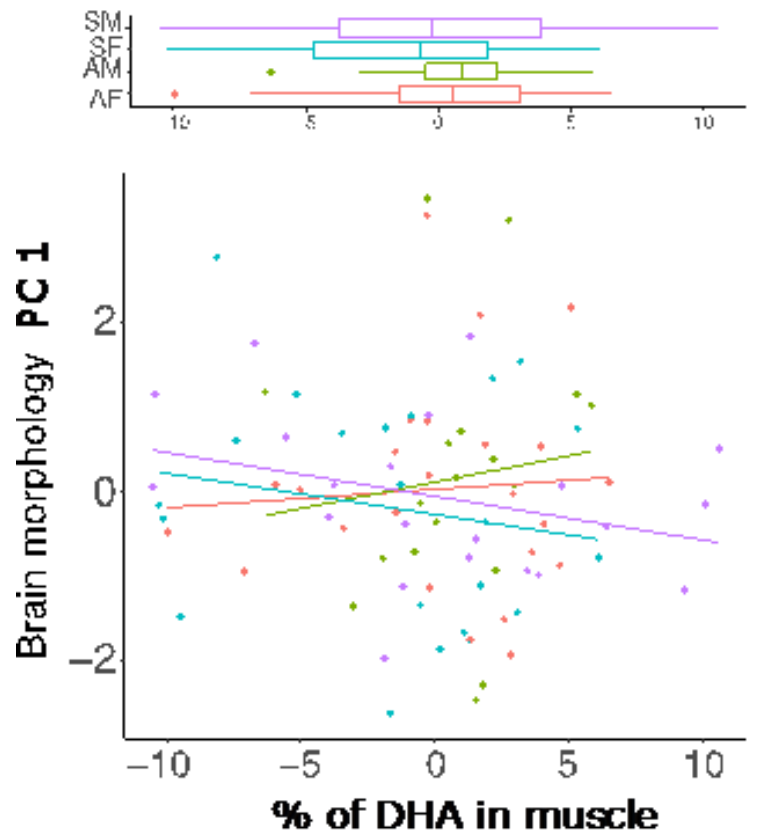

(C)
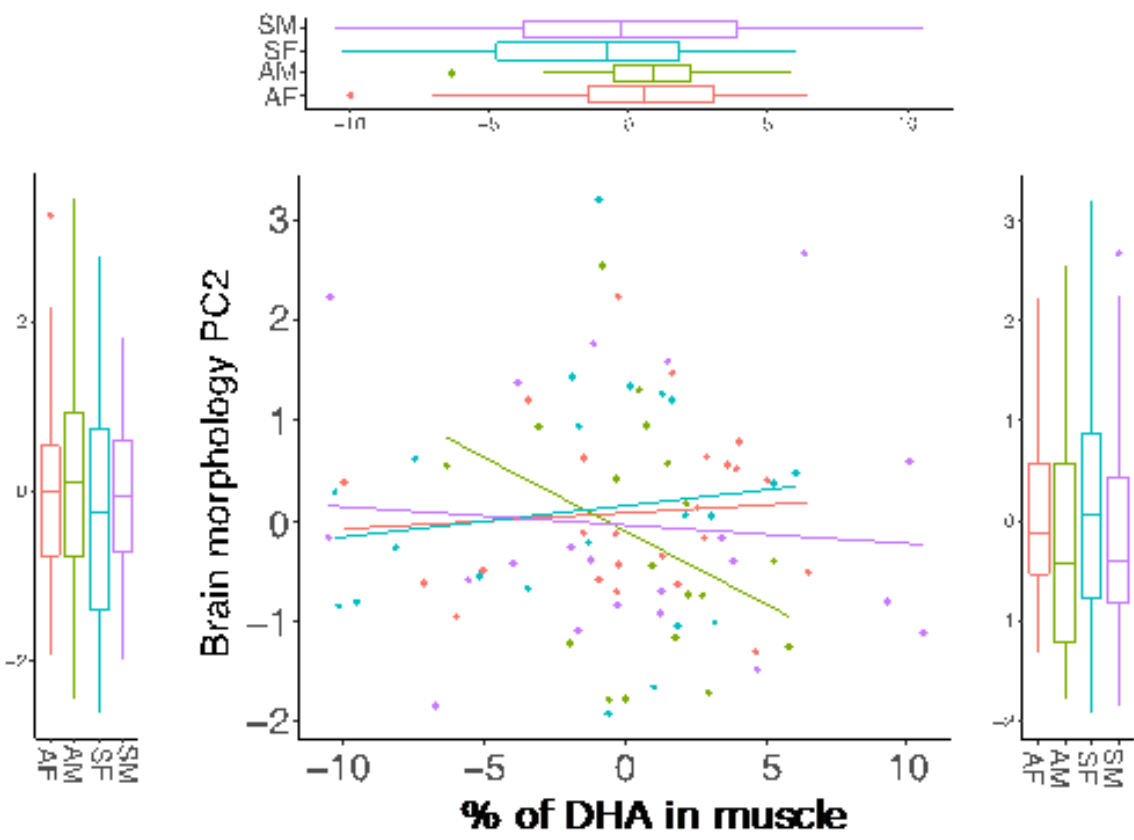

Figure 2

Association between DHA in trout tissues and the brain volume (a), brain morphology PC1 [PC1 was positively related to the volume of olfactory bulb, and hypothalamus and negatively related to cerebellum and optic tectum] (b) and brain morphology PC2 [PC2 was positively related to the volume of telencephalon] (c). Colours of datapoints, fit lines and box plots displaying distribution of each variable correspond to AF - allopatric females (red), AM - allopatric males (green), SF - sympatric females (cyan), and SM - sympatric males (purple). All variables are residuals controlled for the fork length of individuals. 


\section{Supplementary Files}

This is a list of supplementary files associated with this preprint. Click to download.

- Supplementary1v4.docx

- Supplementary2v4.docx

- Supplementary3v4.docx 